\title{
PENGARUH PENDEKATAN REALISTIC MATHEMATICS EDUCATION TERHADAP KEMAMPUAN PEMAHAMAN MATEMATIS SISWA SMP NEGERI 11 KENDARI
}

\author{
Sandri Yulia Citra $^{\text {I) }}$, Mustamin Anggo ${ }^{2)}$, Kadir $^{3)}$ \\ 1) Alumni Jurusan Pedidikan Matematika, ${ }^{2,3)}$ Dosen Jurusan Pendidikan Matematika \\ FKIP Universitas Halu Oleo email: sandriyuliacitra@gmail.com; mustaminanggo@yahoo.com; \\ kadirraea@yahoo.co.id
}

\begin{abstract}
Abstrak
Penelitian ini dilatarbelakangi oleh rendahnya kemampuan pemahaman matematis siswa. Populasi dalam penelitian ini adalah seluruh siswa kelas VII SMP Negeri 11 Kendari yang tersebar di 4 kelas paralel dengan jumlah 101 siswa. Teknik pengambilan sampel dalam penelitian dilakukan secara purposive sampling. Teknik pengumpulan data dilakukan dengan pemberian tes kemampuan pemahaman berbentuk tes uraian. Berdasarkan hasil analisis data dan pembahasan diperoleh kesimpulan: (1) kemampuan pemahaman matematis siswa yang diajar dengan pendekatan Realistic Mathematics Education (RME) pada materi bentuk aljabar memiliki nilai minimum 62.50; nilai maksimum 91.67; nilai rata-rata 75.50; standar deviasi 8.45; varians 71.35; median 75.00 dan modus 75.00 , (2) kemampuan pemahaman matematis siswa yang diajar dengan pembelajaran konvesional pada materi bentuk aljabar memiliki nilai minimum 37.50; nilai maksimum 79.17 ; nilai rata-rata 62.00; standar deviasi 10.85; varians 117.65; median 62.50; serta modus 62.50 dan 70.83, (3) terdapat pengaruh yang signifikan pendekatan Realistic Mathematics Education (RME) terhadap kemampuan pemahaman matematis siswa.
\end{abstract}

Kata Kunci: realistic mathematics education, pemahaman matematis, standard deviasi

\section{EFFECT OF REALISTIC MATHEMATICS EDUCATION (RME) APPROACH TO THE ABILITY MATHEMATICAL UNDERSTANDING OF STUDENTS SMP NEGERI 11 KENDARI}

\begin{abstract}
This research is motivated by the low ability of students' mathematical understanding. The population in this study is all students of class VII SMP Negeri 11 Kendari spread in 4 parallel classes with the number of 101 students. The sampling technique in this research is done by purposive sampling. Technique of data collecting is done by giving ability comprehension test in form of description test. Based on the result of data analysis and discussion, it can be concluded that: (1) students' mathematical understanding ability which is taught by Realistic Mathematics Education (RME) approach on algebraic material has minimum value of 62.50; the maximum value is 91.67 ; averaging 75.50; standard deviation 8.45 ; variance 71.35 ; median 75.00 and mode 75.00 ; (2) students' mathematical comprehension skills taught by conventional learning on algebraic material have a minimum value of 37.50 ; the maximum value is 79.17 ; average score of 62.00 ; standard deviation 10.85; variance 117.65; median 62.50; and mode 62.50 and 70.83, (3) there is a significant influence of Realistic Mathematics Education (RME) approach to students' mathematical understanding ability.
\end{abstract}

Keywords: realistic mathematics education, mathematical understanding, standard deviation 


\section{Pendahuluan}

Matematika merupakan ilmu dasar yang mendasari perkembangan ilmu-ilmu lain. Oleh karena itu, matematika menjadi salah satu mata pelajaran yang penting untuk diajarkan di sekolah. Ungkapan 'Mathematics for life' and 'mathematics as a human activities' yang diutarakan oleh Freudethal mengartikan bahwa matematika merupakan sebuah aktivitas yang berlaku dan bermanfaat dalam kehidupan seharihari. Setiap aktivitas manusia dalam kehidupan sehari-hari tidak lepas dari peran matematika (Widyastuti dan Pujiastuti, 2014: 184-185).

Pembelajaran matematika, menurut Bruner (Hudoyo, 1998: 56) adalah belajar tentang konsep dan struktur matematika yang terdapat dalam materi yang dipelajari serta mencari hubungan anatara konsep dan struktur matematika di dalamnya. Pembelajaran matematika bagi para siswa merupakan pembentukan pola pikir dalam pemahaman maupun dalam penalaran suatu hubungan diantara pengertian-pengertian itu. Dalam pembelajaran matematika, para siswa dibiasakan untuk memperoleh pemahaman melalui pengalaman tentang sifat-sifat yang dimiliki dan yang tidak dimiliki dari sekumpulan objek (abstraksi). Siswa diberi pengalaman menggunakan matematika sebagai alat untuk memahami atau menyampaikan informasi, misalnya melalui persamaaan-persamaan, atau tabel-tabel dalam model-model matematika yang merupakan penyerdahanaan dari soal-soal cerita atau soal-soal uraian matematika lainnya.

Yulaelawati (2004: 24) menyatakan bahwa pembelajaran matematika yaitu pembelajaran yang hendaknya difokuskan pada proses, struktur, dan pemecahan masalah, bukan hanya sekedar menjawab soal. Hal ini bias dilakukan dengan cara memberi peserta didik soal yang bervariasi, yang menuntut prosedur pemecahan yang juga bervariasi.

Pembelajaran matematika realistik memanfaatkan dunia nyata (real world) sebagai titik awal pengembangan ide dan konsep matematika. De Lange menyatakan "Real world as a concrete real world which is transferred to students through mathematical application". Artinya, dunia nyata sebagai suatu dunia yang konkret yang disampaikan kepada siswa melalui aplikasi matematika. Berawal dari sinilah dikembangkan proses pembelajaran matematika berdasarkan situasi yang dipahami, berhubungan dengan siswa dan dekat dengan lingkungan siswa. Hal itu dapat digambarkan dengan skema 1.

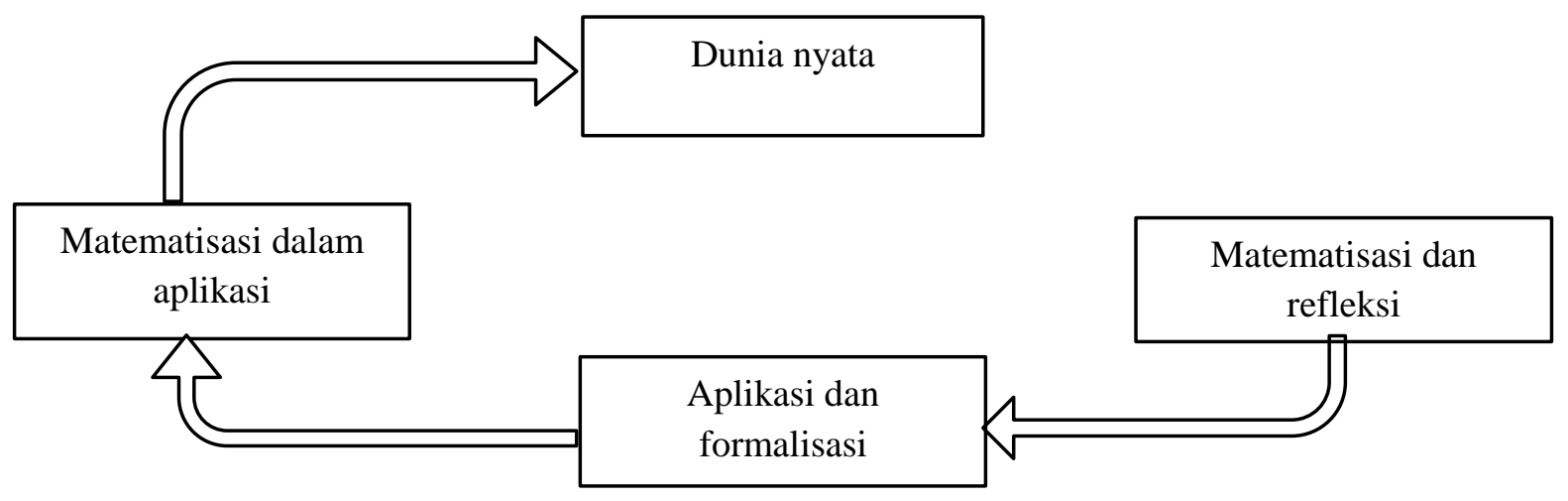

Gambar 1. Konsep Matematisasi

Skema proses pembelajaran seperti di atas menunjukkan bahwa pembelajaran merupakan suatu siklus yang menempatkan suatu proses sebagai salah satu poin utama. Artinya proses lebih diutamakan dibandingkan produk yang dihasilkan (Shadiq \& Amini, 2010: 9).

Menurut Yuhasriati (2012: 85), masalah nyata yang dimaksud bukan hanya karena titik tolak pembelajaran berhubungan dengan dunia nyata dalam arti sehari-hari, tetapi juga menekankan pembelajaran dengan menyajikan situasi yang dapat dibayangkan (to image) oleh siswa itu sendiri. Jadi penekanannya pada membuat masalah itu menjadi nyata dalam pikiran siswa. Oleh karena itu situasi masalah yang digunakan untuk pembelajaran dengan pendekatan kontekstual harus mempunyai konteks atau kaitan dengan dunia nyata yang dipahami oleh siswa dalam arti sehari-hari, atau berkaitan dengan dunia yang dapat dibayangkan oleh siswa. Dunia nyata yang dapat dibayangkan 
oleh siswa dapat berupa dunia fantasi, dunia dongeng, atau dunia matematika, asal saja dunia itu nyata dalam benak siswa.

Tiga prinsip utama pendekatan Realistic Mathematics Education menurut Gravemeijer (Hobri, 2009: 166) yaitu:

1. Penemuan kembali secara terbimbing melalui matematisasi progresif (Guided Reinvention and Progressive Mathematizing). Menurut prinsip "Guided Reinvention", siswa harus diberi kesempatan mengalami proses yang sama dengan proses yang dilalui para ahli ketika konsep-konsep matematika ditemukan.

2. Fenomena didaktik (Didactical Phenomenology). Menurut prinsip fenomena didaktik, situasi yang mejadi topik matematika diaplikasikan untuk diselidiki berdasarkan dua alasan; (1) Memunculkan ragam aplikasi yang harus diantisipasi dalam pembelajaran, dan (2) Mempertimbangkan kesesuaian situasi dari topik sebagai hal yang berpengaruh untuk proses pembelajaran yang bergerak dari masalah nyata ke matematika formal.

3. Pengembangan model mandiri (selfdeveloped models). Model matematika dimunculkan dan dikembangkan sendiri oleh siswa berfungsi menjembatani kesenjangan pengetahuan informal dan matematika formal, yang berasal dari pengetahuan yang telah dimiliki siswa.

Menurut Hobri (2009: 169-170) ketiga prinsip diatas dioperasionalkan ke dalam karakteristik RME sebagai berikut:

1) Menggunakan masalah kontekstual (the use of context). Pembelajaran dimulai dengan menggunakan masalah kontekstual sebagai titik tolak atau titik awal untuk belajar. Masalah kontekstual yang menjadi topik pembelajaran harus merupakan masalah sederhana yang dikenali siswa.

2) Menggunakan model (use models, bridging by vertical instruments). Model disini sebagai jembatan antara real abstrak yang membantu siswa belajar matematika pada level abstraksi yang berbeda. Istilah model berkaitan dengan model situasi dan model matematik yang dikembangkan oleh siswa sendiri (self-develop models). Peran selfdevelop models merupakan jembatan bagi siswa dari situasi real ke situasi abstrak atau dari matematika informal ke matematika formal. Artinya siswa membuat model sendiri dalam menyelesaikan masalah. Pertama model situasi yang dekat dengan dunia nyata siswa. Generalisasi dari formalisasi model tersebut akan berubah menjadi model-of masalah tersebut. Melalui penalaran matematik model-of akan bergeser menjadi model-for masalah yang sejenis. Pada akhirnya, akan menjadi model matematika formal.

3) Menggunakan kontribusi siswa (student contribution). Kontribusi yang besar pada proses belajar mengajar diharapkan datangnya dari siswa. Hal ini berarti semua pikiran (konstruksi dan produksi) siswa diperhatikan.

4) Interaktivitas (interactivity). Interaksi antarsiswa dengan guru merupakan hal yang mendasar dalam RME. Secara eksplisit bentuk-bentuk interaksi yang berupa negosiasi, penjelasan, pembenaran, setuju, tidak setuju, pertanyaan atau refleksi digunakan untuk mencapai bentuk formal dari bentuk-bentuk informal siswa.

5) Terintegrasi dengan topik lainnya (intertwining). Dalam RME pengintegrasian unit-unit matematika adalah esensial. Jika dalam pembelajaran kita mengabaikan keterkaitan dengan bidang yang lain, maka akan berpengaruh pada pemecahan masalah. Dalam mengaplikasikan matematika, biasanya diperlukan pengetahuan yang lebih kompleks.

Menurut Yuwono (2007: 4) Sintaks pembelajaran matematika realistik dapat dilaksanakan melalui 4 fase yaitu:

Fase 1 : Memahami Masalah Kontekstual Aktivitas Guru :

a) Memberikan masalah kontekstual Masalah yang diberikan sesuai dengan konteks siswa. Masalah yang disajikan tidak harus konkret, tetapi dapat juga sesuatu yang dipahami atau dapat dibayangkan siswa. Level konteks ditingkatkan dari informal menuju formal.

b) Meminta siswa memahami masalah tersebut.

c) Menjelaskan situasi dan kondisi masalah dengan cara memberikan petunjuk seperlunya terhadap bagian tertentu yang belum dipahami oleh siswa. Penjelasan diberikan terbatas sampai siswa mengerti maksud masalah. 
d) Memberikan pertanyaan pancingan agar terarah pada pemahaman masalah kontekstual tesebut apabila siswa kesulitan dalam memahami masalah kontekstual.

Aktivitas Siswa :

a) Memahami masalah kontektual yang diberikan guru.

b) Secara aktif mengkontruksikan pemahaman dan pengetahuannya sendiri dengan cara mengaitkan penjelaan guru dengan pengetahuan dan pengalaman yang dimiliki.

c) Bertanya kepada guru bila masih ada yang belum dipahami dari masalah tersebut.

Fase 2 : Memahami Masalah Kontekstual

Aktivitas Guru :

a) Memberikan petunjuk berupa pertanyaan "Apa yang dapat kamu ketahui dari masalah tersebut?; bagai-mana kamu tahu itu?; Bagaimana mendapatkannya?; Mengapa kamu berpikir demikian?; dan lain-lain.

b) Memberikan kesempatan kepada siswa untuk menyelesaikan masalah yang disajikan sehingga dapat menemukan kembali konsep-konsep matematika sesuai dengan pengalaman siswa tersebut.

c) Memberikan dorongan agar siswa secara mandiri/ kelompok dalam menyelesaikan masalah yang disajikan.

d) Membangun interaksi dinamis antara siswa dan siswa serta siswa dengan guru.

e) Menerapkan pendekatan individual sehingga dapat memberikan perlakuan kepada siswa sesuai dengan kebutuhan dan karakteristiknya.

Aktivitas Siswa :

a) Menyelesaikan masalah dengan cara mereka sendiri.

b) Membangun kerjasama interaktif antar siswa maupun siswa dan guru agar proses pemecahan masalah dapat diselesaikan dengan baik. Melalui interaksi tersebiut diharapkan terjadi proses saling membantu. Dalam menyelesaikan masalah kontekstual, dapat digunakan model berupa benda manipulatif, skema atau diagram untuk menjembatani kesenjangan antara konkret dan abstrak atau dari abstraksi yang satu ke abstrak selanjutnya.

Fase 3 : Membandingkan dan Mendiskusikan Jawaban

Aktivitas Guru :

a) Memberikan kesempatan kepada siswa membandingkan dan mendiskusikan jawaban masalah berkelompok, agar siswa dapat belajar mengemukakan dan menanggapi atau menerima pendapat orang lain.

b) Memberikan dorongan agar semua siswa berpartisipasi memberikan kontribusi selama diskusi.

c) Memberikan penghargaan kepada siswa yang secara aktif menyampaikan gagasan atau sumbangsi pikiran agar terjadi pertukaran ide dalam proses pembelajaran.

Aktivitas Siswa :

a) Melalui perwakilan siswa atau kelompok memaparkan hasil pemecahan masalah kepada teman lain.

b) Berkomunikasi dan memberikan sumbangan atau gagasan kepada siswa lain.

c) Memproduksi dan mengkonstruksi gagasan mereka sehingga proses pembelajaran menjadi konstruktif dan produktif.

d) Membandingkan hasil temuannya masingmasing dengan temuan siswa lainnya.

e) Menyampaikan pendapat untuk menemukan pemecahan masalah yang lebih baik untuk meningkatkan level belajar.

Fase $4 \quad$ : Menyimpulkan

Aktivitas Guru :

a) Mengarahkan siswa menarik kesimpulan suatu konsep matematika berdasarkan hasil membandingkan dan mendiskusikan jawaban.

b) Memberikan kesempatan kepada siswa untuk membuat kesimpulan sendiri melalui masalah yang disajikan tersebut.

c) Mengarahkan siswa pada kesimpulan yang sesungguhnya.

Aktivitas Siswa :

a) Menyimpulkan pemecahan atas masalah yang disajikan berdasarkan hasil membandingkan dan mendiskusikan jawaban dengan siswa lain.

b) Memformulasikan kesim-pulan sebagai proses antara pengetahuan informal dan matematika formal.

Walle (2008: 26), "pemahaman dapat didefinisikan sebagai ukuran kualitas dan kuantitas hubungan suatu ide dengan ide yang telah ada". Setiap siswa memiliki kemampuan pemahaman yang berbeda tergantung pada ide 
yang dimiliki dan pembuatan hubungan antara ide yang ada dengan ide baru.

Pemahaman akan sebuah konsep ilmu pengetahuan yang sedang dipelajari memiliki peranan yang sangat penting. Siswa akan berkembang ke jenjang kognitif yang lebih tinggi jika ia memiliki pemahaman konsep yang baik. Jika pemahaman konsep dikuasai dengan baik maka siswa akan mampu menghubungkan atau mengaitkan sebuah konsep yang satu dengan yang lainnya. Selain itu, konsep tersebut dapat digunakan untuk memecahkan permasalahan dari mulai yang sederhana hingga ke permasalahan yang lebih kompleks.

$$
\text { Ruseffendi (2006: 221), }
$$
mengkategorikan pemahaman menjadi tiga macam, yaitu:

a) pengubahan (penerjemahan);

b) pemberian arti (interpretasi);

c) pembuatan ekstrapolasi.

Pengubahan (penerjemahan), yaitu kemampuan untuk mengubah atau menerjemahkan simbol ke dalam kata-kata dan sebaliknya, mampu mengartikan suatu kesamaan dan mampu mengkonkritkan konsep yang abstrak. Pemberian arti (interpretasi), yaitu kemampuan untuk memahami sebuah konsep yang disajikan dalam bentuk lain seperti diagram, tabel, grafik dan lain-lain. Sedangkan Pembuatan ekstrapolasi, yaitu kemampuan untuk memperkirakan atau meramalkan suatu kecenderungan yang ada menurut data tertentu.

Skemp (1976) membedakan pemahaman ke dalam tiga macam, yaitu:
a) pemahaman instrumental (instrumental understanding);
b) pemahaman relasional (relational understanding);
c) pemahaman logis (logical understanding).
Pemahaman instrumental adalah

kemampuan seseorang menggunakan prosedur matematis untuk menyelesaikan suatu masalah tanpa mengetahui mengapa prosedur itu digunakan. Dengan kata lain siswa hanya mengetahui "bagaimana" tetapi tidak mengetahui "mengapa". Pada tahapan ini, pemahaman konsep masih terpisah dan hanya sekedar hafal suatu rumus untuk menyelesaikan permasalahan rutin/sederhana sehingga siswa belum mampu menerapkan rumus tersebut pada permasalahan baru yang berkaitan. Sementara itu, pemahaman relasional adalah kemampuan seseorang menggunakan prosedur matematis dengan penuh kesadaran bagaimana dan mengapa prosedur itu digunakan. Secara ringkasnya, siswa mengetahui keduanya yaitu "bagaimana" dan "mengapa". Pada tahap ini, siswa dapat mengaitkan antara satu konsep atau prinsip dengan konsep atau prinsip lainnya dengan benar dan menyadari proses yang dilakukan. Sedangkan pemahaman logis berkaitan erat dengan meyakinkan diri sendiri dan meyakinkan orang lain. Dengan kata lain, siswa dapat mengkonstruksi sebuah bukti sebelum ide-ide yangdimilikinya dipublikasikan secara formal atau informal sehingga membuat siswa tersebut merasa yakin untuk membuat penjelasan kepada siswa yang lain.

Adapun indikator yang digunakan adalah indikator pemahaman konsep menurut Jihad dan Haris (2010: 149), sebagai berikut.

a) kemampuan menyatakan ulang sebuah konsep yang dipelajari;

b) kemampuan mengklasifikasikan objek-objek menurut sifat-sifat tertentu (sesuai dengan konsepnya);

c) kemampuan menyebutkan contoh dan noncontoh dari konsep;

d) kemampuan menyajikan konsep dalam berbagai bentuk representasi matematis;

e) kemampuan menggunakan, memanfaatkan dan memilih prosedur atau operasi tertentu;

f) kemampuan mengaplikasikan konsep atau algoritma pemecahan masalah.

g) kemampuan mengembangkan syarat perlu dan syarat cukup suatu konsep;

\section{Metode}

Jenis penelitian ini adalah penelitian quasi eksperimen dengan menggunakan pendekatan pembelajaran realistic mathematics education (RME) di kelas $\mathrm{VII}_{3}$ sebagai kelas eksperimen SMP Negeri 11 Kendari Penelitian ini dilaksanakan di SMP Negeri 11 Kendari pada bulan November 2018 semester ganjil tahun ajaran 2017/2018.

Variabel yang digunakan dalam penelitian ini adalah variabel bebas yaitu perlakuan berupa pembelajaran matematika dengan menerapkan pendekatan realistic mathematics education (RME) dan variabel terikat yaitu kemampuan pemahaman matematis siswa setelah dilakukan pembelajaran matematika dengan pendekatan pendekatan realistic mathematics education (RME).

Penelitian ini menggunakan desain penelitian Posttest Only Control Group Design, 
yaitu dimana dua kelas sampel ditetapkan secara acak, kemudian diberikan perlakuan yang berbeda kemudian diberikan Posttest. Desaian penelitian dapat dilihat pada tabel 1 .

Tabel 1

Desain Penelitian

\begin{tabular}{|c|c|c|}
\hline Kelas & Perlakuan & Posttest \\
\hline Eksperimen & $\mathrm{X}$ & $\mathrm{Y}_{1}$ \\
\hline Kontrol & - & $\mathrm{Y}_{2}$ \\
\hline
\end{tabular}

(Sugiyono, 2015: 114)

Keterangan

$\begin{array}{ll}\mathrm{X} & =\text { skor item } \\ \mathrm{Y} & =\text { skor total } \\ \mathrm{N} & =\text { jumlah subyek } \\ & \text { Penentuan reliabilitas hasil uji coba }\end{array}$

$\mathrm{Y}_{1}=$ Hasil Posttest siswa pada kelas eksperimen dengan menggunakan pendekatan Realistic Mathematics Education

$\mathrm{Y}_{2}=$ Hasil Posttest siswa pada kelas kontrol dengan menggunakan pembelajaran konvensional

Populasi dalam penelitian ini adalah seluruh siswa kelas VII SMP Negeri 11 Kendari yang tersebar pada 4 kelas paralel. Teknik pengambilan sampel dilakukan secara purposive sampling, yaitu dengan cara random kelas sehingga terpilih 2 kelas penelitian sebagai yakni kelas eksperimen dan kelas kontrol.

Uji validitas dan reliabilitas instrumen penelitian yang dilakukan pada penelitian ini adalah uji coba instrumen. Analisis validitas instrumen dengan menggunakan rumus :

$$
\mathrm{r}_{\mathrm{XY}}=\frac{\mathrm{N} \sum X Y-\left(\sum X\right)\left(\sum Y\right)}{\sqrt{\left[\mathrm{N}\left(\sum \mathrm{X}^{2}\right)-\left(\sum \mathrm{X}\right)^{2}\right]\left[\mathrm{N}\left(\Sigma \mathrm{Y}^{2}\right)-(\Sigma \mathrm{Y})^{2}\right]}}
$$

(Arikunto, 2010:213)

Keterangan:

$\mathrm{r}_{\mathrm{XY}} \quad=$ korelasi produk moment angka kasar yang dihitung instrumen digunakan rumus Alpha Cronbach sebagai berikut.

$$
\begin{aligned}
& r_{11}=\left(\frac{k}{k-1}\right)\left(1-\frac{\sum \sigma_{b}^{2}}{\sigma_{t}^{2}}\right) \text { (Arikunto, } \\
& \text { 2010:239) }
\end{aligned}
$$

Keterangan:

$\mathrm{r}_{11} \quad=$ reliabilitas instrumen,

$\sum \sigma_{\mathrm{b}}^{2} \quad=$ jumlah varians butir

$\sigma_{\mathrm{t}}^{2} \quad=$ varians total

$\mathrm{k} \quad=$ banyaknya soal

Prosedur pengumpulan data dalam penelitian ini menggunakan metode tes. Metode tes digunakan untuk memperoleh data tentang kemampuan pemahaman matematis siswa pada materi bentuk aljabar. Soal tes ini dalam bentuk uraian. Metode tes ini dilakukan setelah perlakuan diberikan kepada kelas eksperimen dan kelas kontrol dengan tujuan mendapatkan data akhir. Tes diberikan kepada kedua kelas dengan alat tes yang sama dan hasil pengolahan data digunakan untuk menguji hipotesis penelitian. Pedoman penskoran yang digunakan untuk menilai kemampuan pemahaman matematis siswa dapat dilihat pada tabel 2 . 
Tabel 2

Penskoran Kemampuan Pemahaman Matematis

\begin{tabular}{|c|l|}
\hline Skor & \multicolumn{1}{|c|}{ Sajian jawaban } \\
\hline 4 & $\begin{array}{l}\text { Konsep dan prinsip soal matematika secara lengkap, pnggunaan istilah } \\
\text { dan notasi secara tepat, penggunaan algoritma secara lengkap dan benar. }\end{array}$ \\
\hline 3 & $\begin{array}{l}\text { Konsep dan prinsip terhadap soal matematika hampir lengkap, } \\
\text { penggunaan istilah dan notasi metaematika hampir benar, penggunaan } \\
\text { algoritma secara lengkap, perhitungan secara umum mengandung sedikit } \\
\text { kesalahan. }\end{array}$ \\
\hline 2 & $\begin{array}{l}\text { Konsep dan priensip terhadap soal matematika kurang lengkap, jawaban } \\
\text { mengandung prhitungan yang salah }\end{array}$ \\
\hline 1 & $\begin{array}{l}\text { Konsep dan prinsip terhadap soal matematika sangat terbatas, jawaban } \\
\text { sebagian besar mengandung perhitungan yang salah. }\end{array}$ \\
\hline 0 & $\begin{array}{l}\text { Tidak menunjukan pemahaman konsep dan prinsip terhadap soal } \\
\text { matematika. }\end{array}$ \\
\hline
\end{tabular}

(Rani, 2017:32)

Penelitian ini dilakukanlah pengujian hipotesis (uji-t) dengan terlebih dahulu dilakukan uji normalitas data dan uji homogenitas data sebagai uji prasyarat untuk melakukan uji hipotesis. Rumus uji-t yang digunakan adalah Independent Samples Test. Dengan kriteria pengambilan keputusan sebagai berikut:

Terima $\mathrm{H}_{0}$ Jika $\mathrm{t} \leq t_{(1-\alpha ; n 1+n 2-2)}$ dengan taraf kesalahan $\alpha=0,05$.

\section{Hasil}

Hasil observasi terhadap pelaksanaan pembelajaran matematika dengan menggunakan

Tabel 3

Deskripsi Keberhasilan Pengelolaan Pembelajaran oleh Guru Kelas Eksperimen pendekatan RME pada materi bentuk aljabar dapat dilihat pada tabel 3 .

\begin{tabular}{|c|c|c|c|}
\hline Pertemuan & Skor Total & Persentase (\%) & Kategori \\
\hline I & 18 & $81,81 \%$ & Sangat Baik \\
\hline II & 19 & $86,36 \%$ & Sangat Baik \\
\hline III & 19 & $86,36 \%$ & Sangat Baik \\
\hline IV & 20 & $90,9 \%$ & Sangat Baik \\
\hline V & 20 & $90,9 \%$ & Sangat Baik \\
\hline VI & 21 & $95,45 \%$ & Sangat Baik \\
\hline
\end{tabular}

Berdasarkan tabel 3 hasil observasi terhadap pelaksanaan pembelajaran matematika dengan menggunakan pendekatan RME yang dilakukan oleh guru di kelas eksperimen pada materi bentuk aljabar, keberhasilan pengelolaan pembelajaran pada pertemuan pertama sudah masuk dalam kriteria sangat baik. Secara keseluruhan, guru telah melaksanakan rangkaian kegiatan pembelajaran sesuai dengan pendekatan RME, akan tetapi guru sering melupakan langkah-langkah kegiatan di awal dan akhir pembelajaran. Namun pada kegiatan inti secara keseluruhan sudah dilaksanakan dengan cukup baikRata-rata persentase pelaksanaan pembelajaran dengan pendekatan
RME dari pertemuan pertama sampai pertemuan keenam yakni $88,63 \%$.

Kekurangan-kekurangan yang dilakukan guru pada proses pembelajaran di kelas eksperimen, disebabkan karena guru masih berusaha menyesuaikan diri dengan kondisi pembelajaran yang baru dan karakteristik siswa yang beragam. Oleh karena itu, untuk memperbaikinya guru lebih menyesuaikan langkah-langkah pembelajaran dengan waktu yang dibutuhkan dan lebih mencoba mengenal dan memahami karakter siswa yang beragam.

Hasil Pengamatan aktivitas siswa pada kelas eksperimen selama pembelajaran dapat dilihat pada tabel 4 . 
Tabel 4

Deskripsi Keaktifan Siswa Selama Pembelajaran Kelas Eksperimen

\begin{tabular}{|c|c|c|c|}
\hline Pertemuan & Skor Total & Persentase (\%) & Kategori \\
\hline I & 36 & $60 \%$ & Cukup \\
\hline II & 44 & $73,34 \%$ & Baik \\
\hline III & 52 & $86,67 \%$ & Sangat baik \\
\hline IV & 55 & $91,67 \%$ & Sangat baik \\
\hline V & 55 & $91,67 \%$ & Sangat baik \\
\hline VI & 56 & $93,34 \% \quad$ Sangat baik \\
\hline
\end{tabular}

Berdasarkan tabel 4 hasil observasi aktivitas siswa dalam pelaksanaan pembelajaran matematika di kelas eksperimen pada materi bentuk aljabar, pada pertemuan pertama ketercapaian seluruh aspek yang diamati adalah $60 \%$. Persentase ini belum dapat dikatakan aktif. Keadaan ini disebabkan karena sebagian siswa masih dalam tahap penyesuaian dengan pemberian LKS yang merupakan situasi yang baru bagi mereka.

Secara umum, ketercapaian keseluruhan aspek yang diamati mengalami peningkatan jika

Tabel 5

Statistik Deskriptif Kemampuan Pemahaman Matematis Siswa

\begin{tabular}{|l|r|r|}
\hline & Eksperimen & \multicolumn{1}{|c|}{ Kontrol } \\
\hline $\mathrm{N}$ & 25 & 25 \\
\hline Mean & 75.5000 & 62.0000 \\
\hline Median & 75.0000 & 62.5000 \\
\hline Mode & 75.00 & $62.50^{\mathrm{a}}$ \\
\hline Std. Deviation & 8.44714 & 10.84668 \\
\hline Variance & 71.354 & 117.650 \\
\hline Minimum & 62.50 & 37.50 \\
\hline Maximum & 91.67 & 79.17 \\
\hline
\end{tabular}

Berdasarkan tabel 5 terlihat bahwa nilai minimum dari kedua kelas berbeda, nilai 62.50 untuk kelas eksperimen dan nilai 37.50 untuk kelas kontrol. Begitu pula yang terjadi dengan nilai maksimumnya, yaitu nilai 91.67 untuk kelas eksperimen dan nilai 79.17 untuk kelas kontrol. Nilai rata-rata (mean) terbesar yaitu 75.50 yang mewakili keseluruhan distribusi nilai kemampuan pemahaman matematis siswa untuk kelas eksperimen, sedangkan nilai rata-rata kelas 62.00 mewakili keseluruhan distribusi nilai kemampuan pemahaman matematis siswa untuk kelas kontrol. Dari segi rata-rata terlihat bahwa nilai rata-rata kemampuan pemahaman kelas eksperimen lebih baik dari kelas kontrol. Nilai tengah (median) untuk kelas eksperimen yaitu pertemuan pertama. Secara keseluruhan rata-rata persentase keaktifan siswa dari pertemuan pertama sampai pertemuan keenam yakni mencapai $82,78 \%$, yang berarti siswa sudah tergolong aktif.

Berdasarkan hasil analisis deskriptif data kemampuan pemahaman matematis siswa kelas eksperimen dan kelas kontrol menggunakan bantuan SPSS dapat dilihat pada tabel 5.

75.00 dan kelas kontrol yaitu 62.50. Nilai modus untuk kelas eksperimen yaitu 75.50 dan nilai 62.50 dan 70.83 untuk kelas kontrol.

Standar deviasi (Std. Deviation) untuk kelas kontrol lebih tinggi dari pada kelas eksperimen yakni 10.85 dan 8.45. Hal ini menunjukan bahwa data kemampuan pemahaman kelas kontrol lebih beragam dibanding kelas eksperimen. Dengan kata lain kelas kontrol antara siswa yang berkemampuan tinggi dengan siswa yang berkemampuan rendah mempunyai selisih kemampuan pemahaman yang lebih besar dibanding kelas eksperimen. Secara umum deskrirptif statistik kemampuan pemahaman matematis kelas eksperimen lebih baik dibanding kelas kontrol. Distribusi nilai 
kemampuan pemahaman matematis siswa dapat dilihat pada tabel 6 .

Tabel 6

Distribusi Frekuensi dan Klasifikasi Kemampuan Pemahaman Matematis Siswa Kelas Eksperimen dan Kelas Kontrol

\begin{tabular}{|c|c|c|c|c|c|}
\hline \multirow{2}{*}{ Nilai } & \multirow{2}{*}{$\begin{array}{c}\text { Tingkat } \\
\text { Penguasaan } \\
\text { Siswa }\end{array}$} & \multicolumn{2}{|c|}{$\begin{array}{c}\text { Kelas } \mathrm{VII}_{3} \\
\text { (Eksperimen) }\end{array}$} & \multicolumn{2}{|c|}{$\begin{array}{c}\text { Kelas } \mathrm{VII}_{2} \\
\text { (Kontrol) }\end{array}$} \\
\hline & & Frekuensi & Persentase $(\%)$ & Frekuensi & Persentase $(\%)$ \\
\hline $0 \leq S K K P M<21$ & Kurang sekali & 0 & 0 & 0 & 0 \\
\hline $21 \leq S K K P M<41$ & Kurang & 0 & 0 & 1 & $4 \%$ \\
\hline $41 \leq S K K P M<61$ & Cukup & 0 & 0 & 10 & $40 \%$ \\
\hline $61 \leq S K K P M<81$ & Baik & 19 & $76 \%$ & 14 & $56 \%$ \\
\hline $81 \leq S K K P M \leq 100$ & Baik Sekali & 6 & $24 \%$ & 0 & $0 \%$ \\
\hline Jumlah & & 25 & $100 \%$ & 25 & $100 \%$ \\
\hline
\end{tabular}

Berdasarkan Tabel 6, terlihat bahwa tingkat penguasan kemampuan pemahaman siswa yang mendapat rentang nilai $61 \leq$ matematis siswa di kelas eksperimen lebih baik $S K K P M<81$ (baik) untuk kelas eksperimen dibandingkan dengan tingkat penguasan yaitu $76 \%$ sedangkan untuk kelas kontrol yaitu kemampuan pemahaman matematis siswa di $56 \%$. Untuk siswa yang mendapat nilai $81 \leq$ kelas kontrol. Diagram distribusi data nilai $S K K P M \leq 100$ (baik sekali) untuk kelas kemampuan pemahaman matematis siswa eksperimen yaitu $24 \%$, sedangkan untuk kelas sebagai berikut. kontrol yaitu $0 \%$, ini menunjukkan bahwa

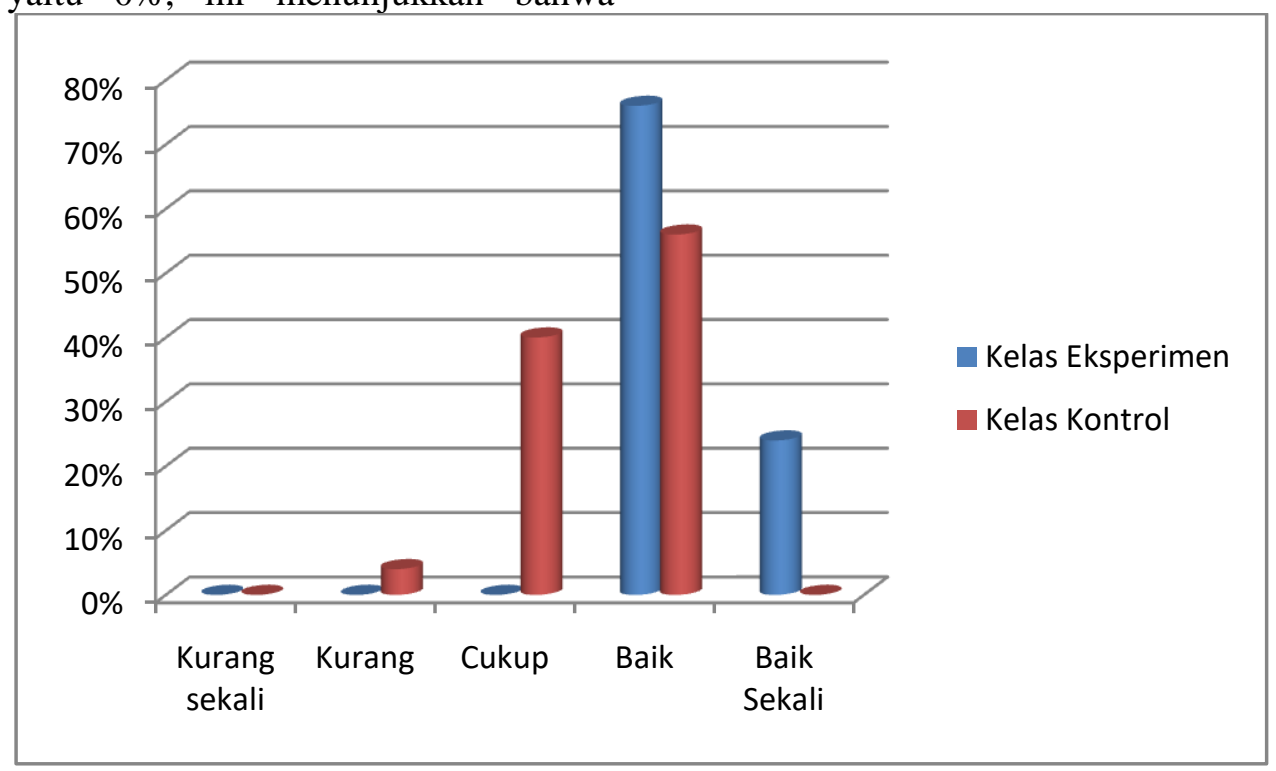

Gambar 2. Diagram Data Kemampuan Pemahaman Matematis Siswa

Gambar 2, menunjukkan bahwa kemampuan pemahaman matematis siswa lebih baik setelah diajar dengan menggunakan pendekatan Realistic Mathematics Education (RME) dibandingkan dengan yang diajar dengan menggunakan pembelajaran konvensional.
Uji normalitas digunakan untuk mengetahui apakah data kemampuan pemahaman matematis berdistribusi normal atau tidak. Untuk menguji apakah data berdistribusi normal atau tidak digunakan statistik uji Kolmogorov-Smirnov dengan bantuan program SPSS. Hasil perhitungannya adalah nilai Asymp. 
Sig. (2-tailed) untuk kelas eksperimen adalah $0,840>\alpha$ (dengan $\alpha=0,05$ ), sehingga $\mathrm{H}_{0}$ diterima dan nilai Asymp. Sig. (2-tailed) untuk kelas kontrol adalah $0,608>\alpha$ (dengan $\alpha=$ 0,05), sehingga $\mathrm{H}_{0}$ diterima. Dengan demikian, dapat disimpulkan bahwa data kemampuan pemahaman matematis siswa berdistribusi normal.

Uji homogenitas digunakan uji levene sengan bantuan SPSS. Hasil perhitungannya adalah nili sig. $(0,149>0,05)$, sehingga $\mathrm{H}_{0}$ diterima. Dengan demikian dapat disimpulkan varians kedua kelas sama (homogen).

Karena data berdistribusi normal dan varians homogen maka untuk menguji pengaruh kemampuan pemahaman matematis siswa digunakan rumus uji-t sampel independen (Independent Samples Test). Rumusan hipotesis statistik yang diuji adalah:

Pasangan hipotesis:

$H_{0}: \mu_{1} \geq \mu_{2} \quad$ lawan $H_{1}: \mu_{1}<\mu_{2}$

Keterangan:

$\mathrm{H}_{0}=$ Tidak terdapat pengaruh yang signifikan pendekatan Realistic Mathematics Education (RME) terhadap kemampuan pemahaman matematis siswa

$\mathrm{H}_{1}=$ Terdapat pengaruh yang signifikan pendekatan Realistic Mathematics Education (RME) terhadap kemampuan pemahaman matematis siswa.

Hasil uji t diperoleh bahwa nilai t hitung lebih besar dari nilai $\mathrm{t}$ tabel ${ }_{(0,05 ; 48)}$ yakni $\left(\mathrm{t}_{\text {hitung }}=\right.$ $4.907>\mathrm{t}_{\text {tabel }}=1.677$ ) sehingga $\mathrm{H}_{0}$ ditolak. Dengan demikian dapat disimpulkan bahwa bahwa terdapat pengaruh yang signifikan pendekatan Realistic Mathematics Education (RME) terhadap kemampuan pemahaman matematis siswa.

\section{Pembahasan}

Jenis penelitian ini adalah eksperimen semu dengan desain Posttest-Only Control Group Design tentang pengaruh pendekatan Realistic Mathematics Education (RME) terhadap kemampuan pemahaman matematis siswa kelas VII SMP Negeri 11 Kendari. Data kemampuan pemahaman matematis siswa diperoleh melalui tes kemampuan pemahaman matematis siswa. Tes yang diberikan setelah perlakuan yaitu tes pada materi bentuk aljabar.

Penelitian ini menggunakan dua kelas sebagai kelas eksperimen dan kelas kontrol.
Kelas eksperimen menggunakan pendekatan Realistic Mathematics Education (RME), sedangkan pada kelas kontrol menggunakan pembelajaran konvesional. Pada kedua kelas siswa diberi tes akhir setelah pembelajaran selesai dilaksanakan. Total pertemuan pada penelitian ini sebanyak 7 kali pertemuan, dengan 6 kali pertemuan digunakan proses pembelajaran dan satu kali pertemuan digunakan untuk tes kemampuan pemahaman matematis siswa pada masing-masing kelas. Selain itu, kedua kelas juga diberi materi yang sama dengan urutan yang sama.

Pengelolaan pelaksanaan pembelajaran oleh guru di kelas Eksperimen dengan materi bentuk aljabar pada pertemuan pertama masuk dalam kriteria baik. Hal ini dapat terlihat dari rekapitulasi pengelolaan pembelajaran yang dicapai oleh guru berada dalam kategori baik. Namun, masih terdapat kekurangan dan perlu ditingkatkan lagi dalam hal pengelolaan pembelajaran. Keadaan ini disebabkan karena guru masih menyesuaikan diri dengan model pembelajaran yang digunakan serta guru masih beradaptasi dengan kondisi kelas dengan karakter siswa yang unik.

Melihat keadaan tersebut, guru berusaha melakukan perbaikan dalam melaksanakan pembelajaran dengan meningkatkan pengelolaan waktu pembelajaran dan mencoba memahami karakter siswa itu sendiri. Sehingga pada pertemuan kedua sampai pada pertemuan kelima kemampuan melaksanakan pembelajaran yang dilakukan guru mengalami kemajuan. Hal ini dapat dilihat dari rekapitulasi ketercapaian indikator pengelolaan pembelajaran oleh guru. Jika dilihat dari nilai ketercapaian aspek yang diamati dari pertemuan kedua sampai dengan pertemuan keenam pada kelas eksperimen memperlihatkan peningkatan yang baik. Secara keseluruhan kemampuan melaksanakan pembelajaran guru baik pada kelas eksperimen dari pertemuan pertama sampai pertemuan keenam sudah dalam kriteria sangat baik dengan persentase rata-rata diatas kriteria efektif.

Pelaksanaan proses pembelajaran, pertama-tama dilakukan kegiatan pendahuluan, yang meliputi pemberian apersepsi, pemberian motivasi dan penyampaian tujuan pembelajaran, kemudian dilakukan pembagian kelompok berdasarkan posisi temapat duduk dengan tujuan untuk mengefisienkan waktu pembelajaran. Dalam proses pembelajaran di kelas ini, siswa 
dibagi menjadi 5 kelompok dengan tiap kelompok beranggotakan 5 siswa. Kemudian pada setiap kelompok diberikan bahan ajar dan LKS untuk dikerjakan secara berkelompok.

Pembelajaran pada kelas eksperimen yaitu pendekatan Realistic Mathematics Education (RME) yang melibatkan empat tahap pembelajaran yaitu memahami masalah kontekstual, menyelesaikan masalah konstekstual, membandingkan dan mendiskusikan jawaban serta menyimpulkan. Pada tahap memahami masalah kontekstual, siswa mengidentifikasi dan memahami masalah pada LKS kemudian menanyakan kepada teman atau guru apabila siswa tidak memahami masalah pada LKS. LKS yang diberikan kepada kelas eksperimen disusun sesuai dengan indikator dan karakteristik pembelajaran pendekatan RME. Pada tahap ini siswa membaca dan mengidentifikasi masalahmasalah pada LKS. Tahap selanjutnya menyelesaikan masalah kontekstual. Pada tahap ini, siswa dituntut untuk menyelesaikan masalah-masalah pada LKS secara berkelompok dengan mengumpulkan data dan mengolah data tersebut untuk memperoleh penyelesaian masalah dalam LKS. Siswa menyelesaikannya dengan berdasarkan pemahaman dasar mereka, serta menggunakan langkah-langkah dan simbol-simbol sesuai pemahaman mereka sendiri. Beberapa siswa yang masih tidak mengerti diarahkan oleh guru dengan memberikan petunjuk-petunjuk yang harus dilakukan.

Guru tidak langsung memberikan langkah-langkah penyelesaian, tetapi hanya mencoba menggali pemahaman siswa sehingga dapat menyelesaikan masalah dengan pendapatnya sendiri. Tahap selanjutnya membandingkan dan mendiskusikan jawaban. Setelah siswa menyelesaikan masalah-masalah pada LKS, siswa saling berdiskusi dan memverifikasi jawaban bersama teman kelompoknya. Siswa dapat mengkomunikasikan gagasan dan jawabannya kepada teman kelompoknya. Setelah diskusi bersama anggota kelompoknya, setiap kelompok mempresentasekan jawabannya kemudian ditanggapi oleh anggota kelompok lain. Tahap ini merupakan kondisi yang memungkinkan siswa untuk mengemukakan pendapat dihadapan teman-temannya, sehingga dapat memotivasi siswa bahwa jawaban mereka patut untuk dihargai, sebagaimana mereka pula belajar untuk menghargai jawaban orang lain.

Tahap terakhir menyimpulkan yaitu, guru membimbing siswa menarik kesimpulan (generalisasi) dan merumuskan bentuk formal. Bentuk formal tersebut dibuat berdasarkan hasil jawaban-jawaban siswa. Guru membimbing siswa merumuskan bentuk formal seakan-akan bentuk tersebut hasil temuan mereka sendiri. Rangkaian tahap-tahap dalam pembelajaran ini sangat menekankan kepada siswa agar mampu menyelesaikan suatu masalah kontekstual dengan idenya sendiri, sehingga materi palajaran dapat mudah diingat oleh siswa dan tidak mudah dilupakan serta dapat melatih dan meningkatkan kemampuan pemahaman konsep matematis pada siswa.

Berdasarkan hasil pengamatan guru terhadap sikap siswa selama pembelajaran, pada pertemuan pertama dan kedua, siswa masih nampak ragu-ragu dalam bertindak dan menyampaikan pendapat. Selanjutnya mulai pertemuan ketiga sikap siswa sudah mulai aktif. Sudah banyak siswa menunjukkan sikap responsif, rasa ingin tahu, logis, kritis dan tidak mudah menyerah. Siswa sudah mulai bertanggung jawab terhadap tugas yang diberikan serta teliti dalam menyelesaikan masalah-masalah yang diberikan. Dalam proses mengamati, antusiasme siswa cukup besar, hal ini terlihat sejak pertemuan pertama, dimana siswa semangat menjalankan instruksi yang diberikan. Selama proses pembelajaran juga diketahui beberapa siswa sudah memiliki keterampilan sosial yang baik. Hal ini ditunjukkan dari beberapa hal antara lain: (1) cara bertanya siswa yang sopan kepada guru maupun temannya, (2) siswa menghargai pendapat yang berbeda (3) siswa dapat memberikan ide atau pendapat yang baik, (4) siswa menjadi pendengar yang baik, dan (5) siswa dapat bekerja sama dengan teman yang lain. Walaupun ada beberapa siswa yang kadang kurang aktif dalam kelompok belajar, karena sesungguhnya hal itu adalah kebiasaan dan karakter yang sudah dimiliki oleh siswa yang bersangkutan. Selain itu dari segi keterampilan dalam menyelesaikan masalah, siswa sudah cukup bagus. Ini terlihat dari, siswa sudah dapat memilih dan menerapkan konsep yang sesuai untuk penyelesaian suatu masalah. Hal lain yang terlihat adalah adanya keragaman cara dan jawaban siswa dalam menyelesaikan suatu masalah yaitu siswa dapat menyelesaikan 
masalah yang berkaitan dengan materi bentuk aljabar.

Data kemampuan pemahaman matematis diperoleh melalui tes kemampuan pemahaman matematis. Tes tersebut diberikan kepada siswa kelas eksperimen dan kelas kontrol, setelah perlakuan. Setelah dilaksanakan pembelajaran pada kelas eksperimen dengan menggunakan pendekatan Realistic Mathematics Education (RME) dan pada kelas kontrol dengan menggunakan pembelajaran konvesioanl, diperoleh data dengan tes akhir kemampuan pemahaman matematis siswa. Skor yang diberikan pada siswa sesuai dengan pedoman penskoran kemampuan pemahaman matematis siswa.

Berdasarkan hasil lembar jawaban tes akhir siswa bahwa pada kelas eksperimen siswa paling banyak mendapatkan skor 4 hampir pada setiap soal dibandingkan dengan kelas kontrol. Ini menunjukan bahwa siswa di kelas eksperimen, konsep dan prinsip soal matematika secara lengkap, penggunaan istilah dan notasi secara tepat, penggunaan algoritma secara lengkap dan benar lebih baik daripada kelas kontrol. Sedangkan pada kelas kontrol siswa paling banyak mendapatkan skor 3 yaitu konsep dan prinsip terhadap soal matematika hampir lengkap, penggunaan istilah dan notasi matematika hampir benar, penggunaan algoritma secara lengkap, perhitungan secara umum mengandung sedikit kesalahan untuk setiap butir soalnya.

Berdasarkan hasil analisis deskriptif data tes akhir pada tabel 5, kemampuan pemahaman matematis siswa pada kelas eksperimen diperoleh nilai maksimum 91.67 sebanyak 2 orang dan nilai minimum 62.5 sebanyak 3 orang, dengan rata-rata kelas adalah 75.50. Sedangkan untuk kelas kontrol, diperoleh nilai maksimum 79.17 sebanyak 1 orang dan nilai minimum 37.50 sebanyak 1 orang, dengan rata-rata kelas adalah 62.00 Standar deviasi kelas eksperimen adalah 8.45 lebih kecil dari standar deviasi kelas kontrol adalah 10.85. Hal tersebut menunjukan bahwa siswa kelas eksperimen lebih baik dari kelas kontrol.

Berdasarkan distribusi frekuensi dan klasifikasi kemampuan pemahaman metematis siswa kelas eksperimen dan kelas kontrol menunjukkan bahwa tingkat penguasaan kemamapuan pemahaman matematis siswa di kelas eksperimen lebih baik dibandingkan dengan tingkat penguasaan kemampuan matematis siswa di kelas kontrol. Ini sesuai dengan standar kriteria kemampuan pemahaman matematis (SKKPM) dengan tingkat penguasaan dikatakan baik sebesar $76 \%$, dan tingkat penguasaan siswa yang dikatakan baik sekali sebesar $24 \%$ pada kelas eksperimen sedangkan pada kelas kontrol hanya sebesar 56\% untuk tingkat penguasaan dikatakan baik dan untuk tingkat penguasaan dikatakan baik sekali $0 \%$.

Mengetahui pengaruh penggunaan pendekatan Realistic Mathematics Education (RME) terhadap kemampuan pemahaman matematis siswa, dilakukan uji hipotesis kemampuan pemahaman matematis pada kedua kelas dengan menggunakan uji $\mathrm{T}$ Sample independent. Dengan terlebih dahulu melewati uji prasyarat yaitu uji normalitas data kelas eksperimens dan kelas kontrol serta uji homogenitas varians data kedua kelompok sampel. Berdasarkan perhitungan dengan uji statistik kolmogorof-smirnov dan berdasarkan hasil analisis statistik uji normalitas data tes akhir diperoleh untuk data kemampuan pemahaman matematis kelas eksperimen dan kelas kontrol berdistribusi normal. Selanjutnya, berdasarkan perhitungan uji homogenitas uji-F dan berdasarkan tabel 4.6 hasil uji homogenitas data kemampuan pemahaman matematis siswa pada kelas eksperimen dan kelas kontrol menggunakan uji levene, diperoleh bahwa data kemampuan pemahaman matematis kedua kelompok mempunyai varians yang homogen.

Berdasarkan hasil uji hipotesis melalui penghitungan hasil uji t Independent Sample Tes pemahaman matematis siswa bahwa terdapat pengaruh yang signifikan pendekatan Realistic Mathematics Eduction (RME) terhadap kemampuan pemahaman matematis siswa. Hal ini didasarkan pada $t_{\text {hitung }}>t_{\text {tabel }}$ serta nilai signifikansi independent Sample Test yang lebih kecil dari 0,05 yang berarti $\mathrm{H}_{0}$ ditolak. Jadi, terdapat pengaruh yang signifikan pendekatan Realistic Mathematics Education (RME) terhadap kemampuan pemahaman matematis siswa SMP Negeri 11 Kendari.

\section{Simpulan dan Saran}

\section{Simpulan}

Berdasarkan hasil penelitian dan pembahasan, maka dapat ditarik beberapa kesimpulan, yaitu sebagai berikut : 
1. Kemampuan pemahaman matematis pada siswa kelas $\mathrm{VII}_{3}$ SMP Negeri 11 Kendari yang diajar dengan pendekatan Realistic Mathematics Education (RME) pada materi bentuk aljabar memiliki nilai minimum 62.50; nilai maksimum 91.67; nilai rata-rata 75.50 ; standar deviasi 8.45 ; varians 71.35 ; median 75.00 dan modus 75.00 .

2. Kemampuan pemahaman matematis pada siswa kelas $\mathrm{VII}_{2}$ SMP Negeri 11 Kendari yang diajar dengan menggunakan pembelajaran konvensional pada materi bentuk aljabar memiliki nilai minimum 37.50; nilai maksimum 79.17; nilai rata-rata 62.00; standar deviasi 10.85; varians 117.65; median 62.50; serta modus 62.50 dan 70.83 .

3. Terdapat pengaruh yang signifikan pendekatan Realistic Mathematics Education (RME) terhadap kemampuan pemahaman matematis siswa SMP Negeri 11 Kendari. Hal ini didasarkan uji-t dimana $t_{\text {hitung }}>t_{\text {tabel }}$ dan pada signifikansi uji Independent Sampel Test yang lebih kecil dari 0,05 yang berarti $\mathrm{H}_{0}$ ditolak. Jadi dapat disimpulkan bahwa Terdapat pengaruh yang signifikan pendekatan Realistic Mathematics Education (RME) terhadap kemampuan pemahaman matematis siswa SMP Negeri 11 Kendari.

\section{Saran}

Berdasarkan kesimpulan yang diperoleh dalam penelitian ini, maka peneliti memberikan saran-saran seperti berikut ini :

1. Kepada guru yang mengajar mata pelajaran matematika dapat menggunakan pendekatan Realistic Mathematics Education (RME) sebagai salah satu alternatif pembelajaran dalam pembelajaran matematika untuk mengoptimalkan kemampuan pemahaman matematis siswa dalam pembelajaran matematika.

2. Hendaknya kemampuan pemahaman matematis siswa mendapat perhatian khusus dari pihak guru karena setiap materi yang diajarkan harus mengandung unsur pemahaman di dalamnya.

3. Bagi peneliti yang hendak mengembangkan penelitian ini dapat melakukannya pada materi lain atau dengan yang memiliki kemampuan rendah untuk mengembangkan pembelajaran menggunakan pendekatan Realistic Mathematics Education (RME) untuk meningkatkan kemampuan pemahaman matematis siswa.

\section{Daftar Pustaka}

Arikunto, S. (2010). Prosedur Penelitian Suatu Pendekatan Praktek. Jakarta : PT. Rineka Cipta.

Hudoyo, H. (1998). Mengajar Belajar Matematika. Jakarta: Depdikbud.

Hobri. (2009). Model-Model Pembelajaran Inovatif. Jember: Center for Society Studies.

Jihad, A. dan Haris. (2010). Evaluasi Pembelajaran. Yogyakarta: Multi Pressindo.

Rani. (2017). Pengaruh Model Pembelajaran Kooperatif Tipe STAD Terhadap Kemampuan Pemahaman Matematis Siswa Kelas VIII SMP Negeri 11 Kendari. Skripsi. Kendari: Universitas Halu Oleo.

Ruseffendi, E.T. (2006). Pengantar Kepada Membantu Guru Mengembangkan Potensinya dalam Pengajaran Matematika untuk Meningkatkan CBSA. Bandung: Tarsito.

Shadiq F, Amini NM. (2010). Pembelajaran Matematika dengan Pendekatan Realistik di SMP. Modul matematika SMP Program Bermutu. Yogyakarta: Kemendiknas PPPPTK Matematika 2010.

Skemp, R.R. (1976). Relational Understanding and Instrumental Understanding. National Council of Teachers of Mathematics. 77, 20 - 26

Sugiyono. (2015). Statistika untuk Penelitian. Bandung: Alfabeta.

Walle, J.A.V.D. (2008). Matematika Sekolah Dasar dan Menengah Pengembangan Pengajaran. Jakarta: Erlangga.

Widyastuti, N.S. dan P. Pujiastuti. (2014). Pengaruh Pendidikan Matematika Realistik Indonesia (PMRI) terhadap 
Pemahaman Konsep Dan Berpikir Logis Siswa. Jurnal Prima Edukasia, 2 (2):184-185.

Yuhasriati. (2012). Pendekatan Realistik dalam Pembelajaran Matematika. Jurnal Peluang. 1 (1) :81-87.

Yulaelawati, E. (2004). Kurikulum dan Pembelajaran. Jakarta: Pakar Raya.

Yuwono, I. (2007). Model-Model Pembelajaran Inovatif. Surabaya: UM Pres Malang. 